\title{
Assessment of light pollution in parking lots using a measur- ing system with a drone
}

\author{
Magdalena Sielachowska ${ }^{1}$ and Maciej Zajkowski ${ }^{2}$ \\ 1 Department of Photonics, Electronics and Light Technology, Bialystok University of Technology, Bialystok, \\ Poland; m.sielachowska@doktoranci.pb.edu.pl \\ 2 Department of Photonics, Electronics and Light Technology, Bialystok University of Technology, Bialystok, \\ Poland; m.zajkowski@pb.edu.pl \\ * Correspondence: m.sielachowska@doktoranci.pb.edu.pl
}

Citation: Lastname, F.; Lastname, F.; Lastname, F. Title. Energies 2021, 14, x. https://doi.org/10.3390/xxxxx

Academic Editor: Firstname Lastname

Received: date

Accepted: date

Published: date

Publisher's Note: MDPI stays neutral with regard to jurisdictional claims in published maps and institutional affiliations.

Copyright: (c) 2021 by the authors. Submitted for possible open access publication under the terms and conditions of the Creative Commons Attribution (CC BY) license (https://creativecommons.org/license s/by/4.0/).

\begin{abstract}
This article attempts to assess the light pollution of parking lots, using the proprietary measurement method with a drone. The main requirements, reflective features of parking lots and typical light curves of luminaires used in lighting this type of areas were presented. Calculations and simulations for various types of luminaires were performed, and then the obtained results were verified in real conditions. The main factors influencing the increase in light pollution were presented and it was proved that it is possible to use the developed measurement method in order to assess the light pollution degree.
\end{abstract}

Keywords: light pollution; luminous flux; unmanned aerial vehicles

\section{Introduction}

Light pollution, i.e. excessive light beam distribution towards the sky, is mainly the result of incorrectly designed lighting systems. Artificial light that penetrates the upper half-space disturbs not only the functioning of fauna and flora $[1,2,3,4]$, but also disrupts the human biological clock $[5,6,7]$ and disrupts our functioning throughout the day. In large, brightly lit cities, blurring the line between day and night is a problem. Too strong night lighting and the lack of visible sky, caused by the glow of light, make us sleep badly, we are tired and irritable.

The open parkings lighting, which have become an integral part of our landscape, has a significant impact on the increase in light pollution. The main problem in lighting outdoor areas, including parking lots, is the need to take into account many competitive aspects, such as energy efficiency, light pollution, comfort of drivers and road users. Often meeting the basic conditions, i.e. achieving the minimum value of the average illuminance and uniformity, precludes the high energy efficiency of the system. The same goes for light pollution. Most designers believe that the use of luminaires with an appropriate light curve and the correct lighting direction is enough to eliminate the effect of contamination. It does not take into account that the luminous flux is reflected from the ground [8] or the surrounding objects, and then it is sent into the upper half-space, thus generating artificial light pollution of the night sky. What's more, the atmospheric conditions, rarely considered in the research, have a significant impact on the light flux distribution. The value of the stream may vary depending on the air temperature, dew point temperature or humidity. The light will disperse differently during rainfall and snowfall, and it will behave differently in heavy fog [9].

Most of the works and publications focus on reducing energy consumption and effective lighting control in parking lots. Attention is paid to more efficient lighting products and good control mechanisms [10,11,12,13]. This is the right direction, but it is worth reaching a bit further and considering the impact of light pollution itself on modern parking lot lighting systems. At the very beginning, it is worth emphasizing once again that light pollution is an undesirable effect, however, it is not physically possible to eliminate 
this effect completely. The conducted research [14] has shown that light escaping into the upper half-space returns to the ground through reflections from the cloud layer and surrounding objects. This often gives the value of a few additional luxs on the surface of parking lots, which are not taken into account in any calculations. The lighting requirements for parking areas are not high, therefore even a small amount of the luminous flux returning to this area can give noticeable effects while reducing energy consumption for lighting.

The following part of the article presents the basic standards and requirements used in the design of lighting for parking lots. Then, the author's measurement method for the assessment of light pollution degree, with the unmanned aerial vehicles use, was described. Moreover, the results of measurements and simulations for the selected road lighting luminaire are presented, and further research plans are presented.

\section{Standards and requirements in the parking lots lighting}

Lighting requirements for parking lots, such as for roads, sidewalks and pedestrian crossings, are strictly defined. The most important guidelines presenting the minimum average values of illuminance $\left(\mathrm{Em}_{\mathrm{m}}\right)$, uniformity $\left(\mathrm{U}_{0}\right)$ and the required glare factor values $\left(\mathrm{GR}_{\mathrm{L}}\right)$ or color rendering index $(\mathrm{Ra})$ have been collected in the Polish Standard PN-EN 12464-2:2014-05 [15]. The presented standard is a direct translation of the European Standard EN 12464-2: 2014-05 [16]

Table 1. Lighting requirements for parking lots [15]

\begin{tabular}{ccccc}
\hline Type of area, task or activity & $\mathrm{Em}_{\mathrm{m}}[\mathrm{lx}]$ & $\mathrm{U}_{0}$ & $\mathrm{GR}_{\mathrm{L}}$ & $\mathrm{R}_{\mathrm{a}}$ \\
\hline $\begin{array}{c}\text { Light traffic } \\
\text { e.g. parking areas of shops, terraced and } \\
\text { apartment houses, cycle parks } \\
\quad \text { Medium traffic }\end{array}$ & 5 & 0,25 & 55 & 20 \\
$\begin{array}{c}\text { e.g. parking areas of department stores, office } \\
\text { buildings, plants, sports and multipurpose } \\
\text { building complex } \\
\quad \text { Heavy traffic }\end{array}$ & 10 & 0,25 & 50 & 20 \\
$\begin{array}{c}\text { e.g. parking areas of major shopping centres, } \\
\text { major sports and multipurpose building com- } \\
\text { plex }\end{array}$ & 20 & 0,25 & 50 & 20 \\
\hline
\end{tabular}

Additionally, the standard defines the notion of disturbing light coming from external luminaires. The definition of obtrusive light is presented in the standard as obtrusive light which, due to inadequate quantitative, directional or spectral characteristics in a given situation, causes irritation, discomfort, distraction or a reduction in the ability to see relevant information. The obtrusive light was described using five parameters: the light on the real estate $(\mathrm{Ev})$, the luminous intensity of the luminaire (I), the light radiated upwards (ULR), the luminance of the facade $(\mathrm{Lb})$ and the luminance of the signs (Ls). The classification was made for four zones from the completely dark (E1), through the low brightness zone (E2), the medium brightness zone (E3), to the high brightness zone (E4).

Table 2. Maximum obtrusive light permitted for exterior lighting installations [15]

\begin{tabular}{|c|c|c|c|c|c|}
\hline \multirow{2}{*}{$\begin{array}{l}\text { Enviromental } \\
\text { zone }\end{array}$} & \multicolumn{2}{|c|}{$\begin{array}{l}\text { Light on properties } \\
\qquad E_{V}[1 x]\end{array}$} & \multicolumn{2}{|c|}{$\begin{array}{l}\text { Luminaire intensity } \\
\qquad \mathrm{I}[\mathrm{cd}]\end{array}$} & \multirow[t]{2}{*}{$\begin{array}{c}\text { Upward light } \\
\text { ULR [\%] }\end{array}$} \\
\hline & Pre-curfew ${ }^{*}$ & Post-curfew & Pre-curfew ${ }^{*}$ & Post-curfew & \\
\hline E1 & 2 & 0 & 2500 & 0 & 0 \\
\hline E2 & 5 & 1 & 7500 & 500 & 5 \\
\hline
\end{tabular}




\begin{tabular}{llllll}
\hline E3 & 10 & 2 & 10000 & 1000 & 15 \\
E4 & 25 & 5 & 25000 & 2500 & 25 \\
\hline
\end{tabular}

* In case no curfew regulations are available, the higher values shall not be exceeded and the lower values should be taken as preferable limits.

\section{Methodology}

The luminaires used in the parking lots lighting are characterized by different light curves. Below are three examples of outdoor luminaires that are or can be used to illuminate these types of areas.

Table 3. ES SYSTEM luminaires and their light curves [17].

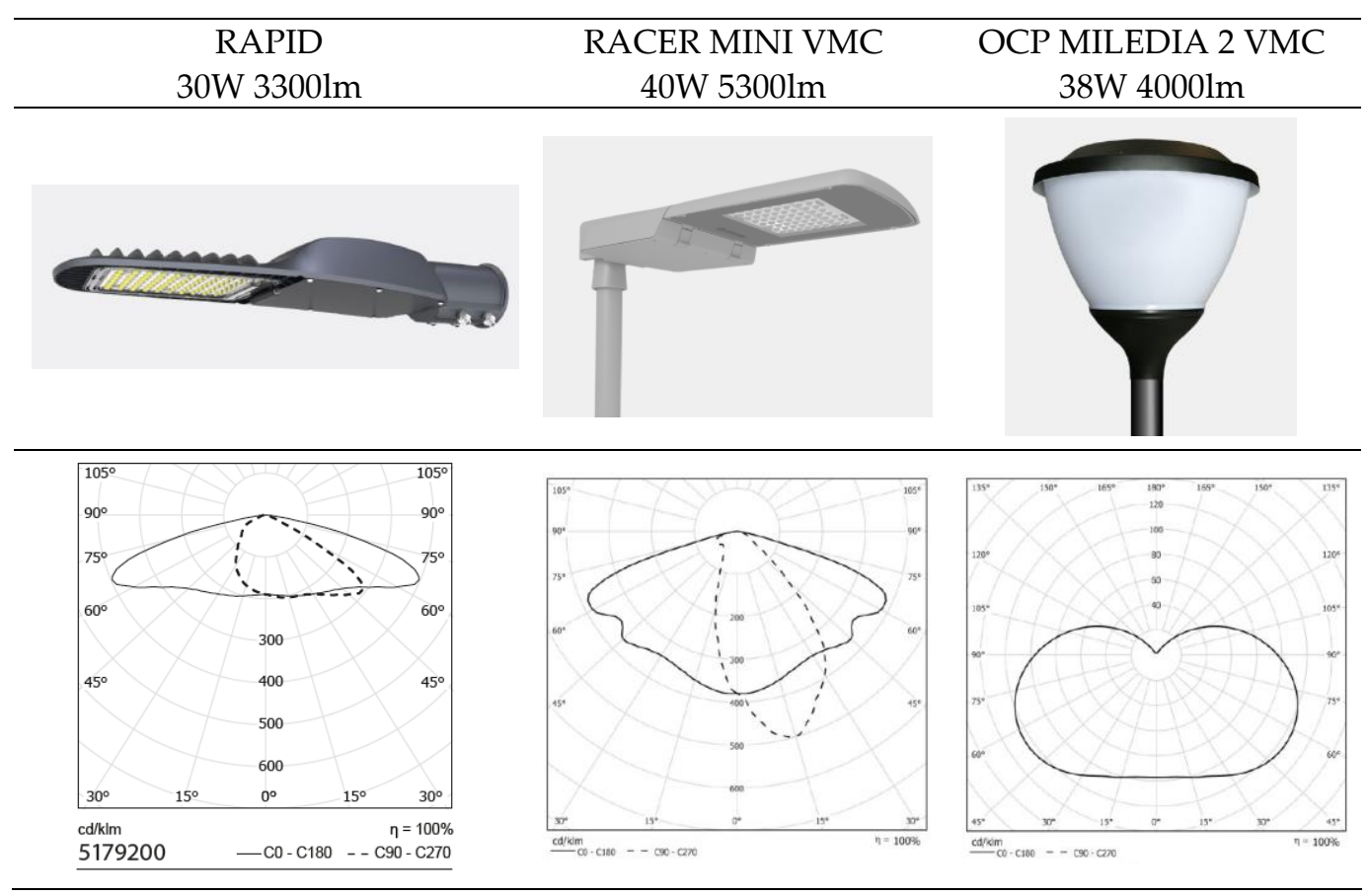

The luminous curves of individual luminaires determine the luminous flux distribution, and thus may, to a greater or lesser extent, affect light pollution. It is possible to identify luminaires that emit the smallest amounts of light towards the sky on the basis of the parameters LPP (lighting pollution percentage) and LPI (light pollution index) [18]. The lower the value of the indicators, the less the effect of the lamp on light pollution.

The LPP (lighting pollution percentage) factor determines the percentage of light pollution in a single luminaire or a group of luminaires and is calculated on the basis of the formula (1) [18].

$$
\mathrm{LPP}=\left(\Phi_{\Lambda} / \Phi_{\mathrm{C}}\right) \cdot 100 \%=\left(\left(\mathrm{E}_{\mathrm{AV}} \cdot \mathrm{S}\right) / \Phi_{\mathrm{C}}\right) \cdot 100 \%
$$

$\Phi_{\Lambda}$ - luminous flux directed into the upper half-space

$\Phi_{C}-$ total luminous flux

$\mathrm{E}_{\mathrm{AV}}$ - average illuminance on the computing area

$\mathrm{S}$ - calculation area Table 4.

The determined values for three exemplary outdoor luminaires are summarized in

Table 4. Calculation results for selected luminaires

\begin{tabular}{cccc}
\hline Luminaire & $\Phi_{\mathrm{C}}[\mathrm{lm}]$ & EAv $[\mathrm{lx}]$ & LPP [\%] \\
\hline
\end{tabular}




\begin{tabular}{cccc}
\hline RAPID & 3300 & 0,33 & 4,00 \\
RACER & 5300 & 0,59 & 4,45 \\
OCP MILEDIA & 4000 & 0,43 & 5,21 \\
\hline
\end{tabular}

The part of the light emitted directly towards the sky can also be described by the socalled ULOR (upward light output ratio), the formula (2) [19].

$$
\mathrm{ULOR}=\left(\Phi_{\mathrm{UP}} / \Phi_{\mathrm{C}}\right) \cdot 100 \%=\left(\left(\mathrm{EŚ́}_{\mathrm{R}} \cdot \mathrm{S}\right) / \Phi_{\mathrm{C}}\right) \cdot 100 \%
$$

$\Phi_{\Lambda}$ - luminous flux emitted into the upper half-space

$\Phi_{C}-$ luminous flux of the light source in the luminaire

For lower light pollution, the ULOR should be as low as possible (preferably 0). Usually, manufacturers provide information on the ULOR value in the luminaire specifications. However, this indicator does not always provide information on the percentage of luminous flux emitted in the upper half of the space [20].

In addition to the luminous intensity curve of the luminaire, important factors that affect how much artificial light escapes into the upper half-space are the reflective and structural features of parking lots, as well as the prevailing weather conditions. The most commonly used materials for the construction of the parking surface are asphalt concrete, cement concrete, concrete pavement, stone pavement (often used for historic areas), or plastics. There are also ground, gravel and grass surfaces. Each of the used substrates will have a different reflectance, which is very important if we analyse the lighting of parking lots in terms of light pollution. The higher the reflectance, the more light will hit the halfspace above. However, it should be remembered that the reflection properties of individual surfaces will change depending on the prevailing weather conditions. Rain, snow, ice - each of these factors means that the reflectance values can increase or decrease significantly. Table 5 shows the real and theoretical values of selected reflectance factors.

Table 5. Light reflectance values depending on the material used

\begin{tabular}{ccc}
\hline Material & Real & Theoretical \\
\hline Snow, ice & - & $0,46-0,87$ \\
Concrete (dry trlin) & 0,22 & \\
Concrete (wet triline) & 0,17 & 0,25 \\
Concrete (snow-covered & 0,42 & \\
triline) & 0,15 & $0,14-0,37$ \\
Grass & 0,11 & 0,20 \\
Tree & &
\end{tabular}

The values were verified under real conditions using a Taylor flectometer. In theory, the reflectivity of the concrete should be 0.25 . In fact, with a dry surface, it turned out to be a bit lower (0.22), for a layer of melting snow, the value almost doubled (0.42), while with wet slabs it dropped significantly (0.17).

Weather conditions affect not only changes in reflectance, but also the light source itself. The RAPID luminaire was tested in a Heraeus VÖTSCH climatic chamber in the range from $-20^{\circ} \mathrm{C}$ to $+50^{\circ} \mathrm{C}$. As a result, it turned out that the luminous flux of the luminaire decreased by about $13 \%$ with increasing temperature (table 6).

Table 6. Test results for a lighting fixture in a climatic chamber

\begin{tabular}{cccc}
\hline LP. & Chamber temperature $\left[{ }^{\circ} \mathrm{C}\right]$ & Case temperature $\left[{ }^{\circ} \mathrm{C}\right]$ & Illuminance $[\mathrm{lx}]$ \\
\hline 1 & -20 & $-2,9$ & 1726 \\
\hline
\end{tabular}




\begin{tabular}{|c|c|c|c|}
\hline 2 & -15 & $-1,6$ & 1718 \\
\hline 3 & -10 & $-0,7$ & 1710 \\
\hline 4 & -5 & 4,7 & 1703 \\
\hline 5 & 0 & 7,7 & 1686 \\
\hline 6 & 5 & 11,9 & 1650 \\
\hline 7 & 10 & 16,0 & 1636 \\
\hline 8 & 15 & 19,5 & 1631 \\
\hline 9 & 20 & 23,6 & 1625 \\
\hline 10 & 25 & 29,1 & 1622 \\
\hline 11 & 30 & 32,9 & 1605 \\
\hline 12 & 35 & 37,1 & 1592 \\
\hline 13 & 40 & 42,5 & 1575 \\
\hline 14 & 45 & 47,1 & 1560 \\
\hline 15 & 50 & 52,0 & 1536 \\
\hline \multicolumn{4}{|c|}{ The illuminance value decreased by 190 lux } \\
\hline 16 & 50 & 54,7 & 1530 \\
\hline 17 & 45 & 54,4 & 1534 \\
\hline 18 & 40 & 53,4 & 1547 \\
\hline 19 & 35 & 50,1 & 1569 \\
\hline 20 & 30 & 46,1 & 1599 \\
\hline 21 & 25 & 42,4 & 1626 \\
\hline 22 & 20 & 38,5 & 1651 \\
\hline 23 & 15 & 35,9 & 1675 \\
\hline 24 & 10 & 30,8 & 1700 \\
\hline 25 & 5 & 26,2 & 1718 \\
\hline 26 & 0 & 19,5 & 1732 \\
\hline 27 & -5 & 14,8 & 1738 \\
\hline 28 & -10 & 9,8 & 1745 \\
\hline 29 & -15 & 5,9 & 1748 \\
\hline 30 & -20 & 1,3 & 1755 \\
\hline
\end{tabular}

\subsection{Measurements and simulations}

In order to estimate the amount of light escaping into the upper half-space, simulations were performed using DIALux simulation software for the three presented road lighting luminaires. Additionally, measurements were carried out in real conditions using the proprietary measurement method for the ES SYSTEM model RAPID luminaire. The area where the selected lamps are located is the existing parking lot, around which there are offices and warehouses. The substrate is made of paving stones, the so-called trilines (Figure 1). 


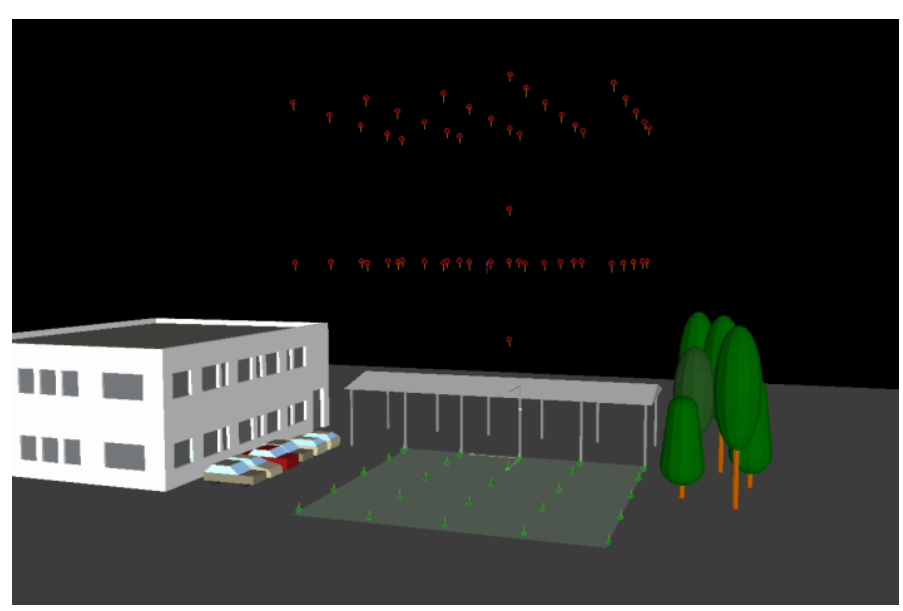

Figure 1. View from DIALux programme

The tested luminaire was placed on a 6-meter-high pole on a $30 \times 40$-meter square in Stanislawowo, near Bialystok. A measuring field of $20 \times 20$ meters on the ground surface and at a height of 10 and 20 meters above the luminaire was adopted in order to determine the degree of light pollution (Figure 2). The highlighted point P8 means a point in the axis with the lighting fixture.

\begin{tabular}{|c|c|c|c|c|c|}
\hline & $10 \mathrm{~m}$ & $5 \mathrm{~m}$ & $0 \mathrm{~m}$ & $5 \mathrm{~m}$ & $10 \mathrm{~m}$ \\
\hline $15 \mathrm{~m}$ & P21 & P22 & P23 & P24 & P25 \\
\hline $10 \mathrm{~m}$ & P16 & P17 & P18 & P19 & P20 \\
\hline $5 \mathrm{~m}$ & P11 & P12 & P13 & P14 & P15 \\
\hline $0 \mathrm{~m}$ & P6 & P7 & P8 & P9 & P10 \\
\hline $5 \mathrm{~m}$ & P1 & P2 & P3 & P4 & P5 \\
\hline & $10 \mathrm{~m}$ & $5 \mathrm{~m}$ & $0 \mathrm{~m}$ & $5 \mathrm{~m}$ & $10 \mathrm{~m}$ \\
\hline
\end{tabular}

Figure 2. Measurement grid

The measurement system was created on the basis of the DJI PHANTOM 3 unmanned aerial vehicles (UAV), equipped with a photometric meter - luxmeter, model OPT3001/OPT3001-Q1 Ambient Light Sensor. Four light meter receivers were positioned around the unmanned aerial vehicle camera (Figure 3). The camera stabilization and the measuring device appropriate positioning is ensured by a precise 3-axis gimbal. Measurement data are recorded by the receiver and saved on the MICRO SD card each time the "SAVE" button is pressed [21]. 


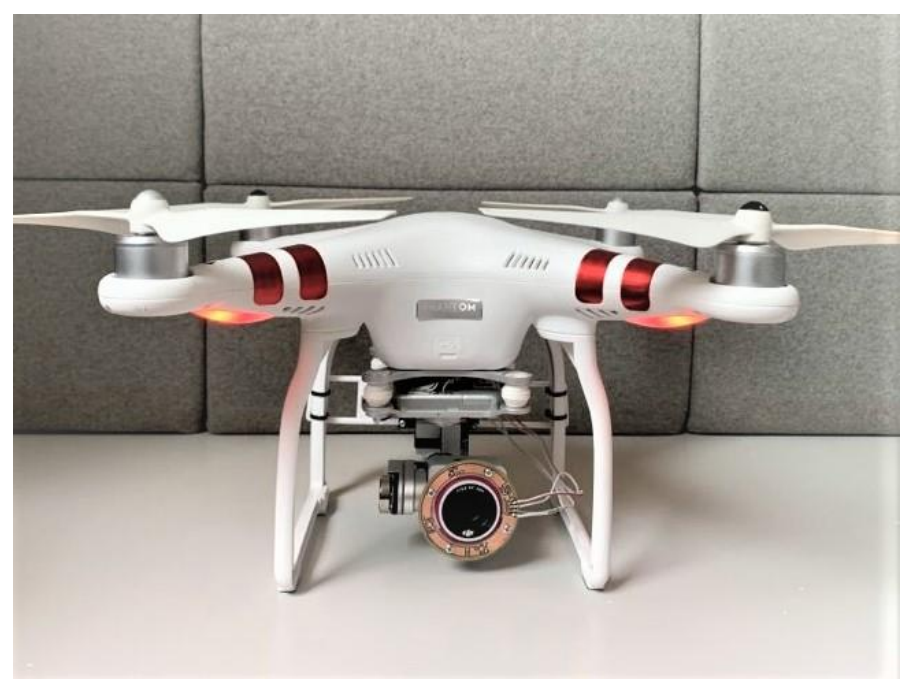

Figure 3. Measuring system

The UVA unmanned aerial vehicle used has a limited operating time. On one battery, in good weather conditions and air temperature above $10{ }^{\circ} \mathrm{C}$, it can work for about 25 minutes. As the temperature drops, and thus also at high altitudes, the operating time is significantly reduced. Keep this in mind and equip yourself with additional batteries. If measurements are made at temperatures below $10^{\circ} \mathrm{C}$, it is necessary to keep spare batteries in a warmer place and activate the device within a few minutes after going outside. [21].

Depending on the method of controlling and moving the drone with a photometric head, it is possible to pilot the aircraft according to the Cartesian coordinate system, in which the movement takes place only vertically in the vertical and horizontal plane (Figure 4, point a), thus limiting positioning errors. However, it is necessary to calculate the photometric distance $r$ in any case. In the spherical system (Figure 4, point b), the photometry distance is kept constant, and the position of the UAV should be calculated for each angle $C$ and $\gamma$. In this configuration, the positioning of the drone should be expected, which will affect the measurement errors in the goniometric system [22].
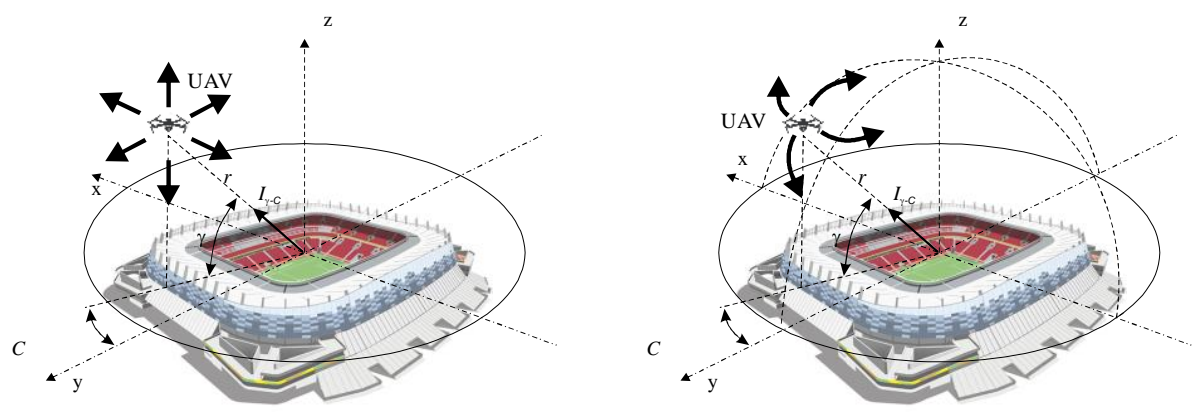

Figure 4. The geometry of the moving UAV to assess the luminous flux emitted by the sports facility: a) straight line, b) spherical [22]

The positioning accuracy of the above method is primarily due to the positioning resolution of the stepper motors that are used to drive the gimbal. Currently available solutions allow for setting the position of the stepper motor shaft with a resolution greater than $1^{1}$, and the repeatability of the setting is carried out with incremental sensors. In photometric measurements such positioning accuracy is acceptable and sufficient when assessing the luminous mass of the light-optical system [23].

In the literature, the presented method is more often used in order to measure the light beam distribution from external lighting fixtures [20, 21, 22, 23, 24, 25]. Most authors introduce their own modifications, however, the method of making measurements and 
the analysis of the obtained results give grounds to claim that the method is reliable and can be used to measure the night sky pollution with artificial light.

\section{Measurements}

The table below summarize the values obtained in the DIALux software for all three road lighting luminaires.

Table 7. Simulation results for selected lighting fixtures

\begin{tabular}{|c|c|c|c|c|c|c|c|c|c|}
\hline \multirow{2}{*}{ 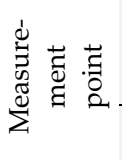 } & \multicolumn{3}{|c|}{$\begin{array}{l}\text { EAv [lx] } \\
\text { Ground }\end{array}$} & \multicolumn{3}{|c|}{$\begin{array}{c}\text { EAv }[\mathrm{lx}] \\
16 \text { meters }\end{array}$} & \multicolumn{3}{|c|}{$\begin{array}{c}\text { EAv }[\mathrm{lx}] \\
26 \text { meters }\end{array}$} \\
\hline & RAPID & RACER & ОСР & RAPID & RACER & $\mathrm{OCP}$ & RAPID & RACER & OCP \\
\hline P1 & 2,53 & 2,23 & 1,44 & 0,21 & 0,37 & 0,42 & 0,12 & 0,22 & 0,15 \\
\hline P2 & 5,30 & 3,41 & 4,25 & 0,25 & 0,51 & 0,35 & 0,14 & 0,25 & 0,17 \\
\hline P3 & 7,98 & 5,93 & 7,45 & 0,23 & 0,51 & 0,39 & 0,13 & 0,23 & 0,17 \\
\hline P4 & 5,29 & 3,39 & 4,24 & 0,26 & 0,52 & 0,35 & 0,14 & 0,25 & 0,17 \\
\hline P5 & 2,55 & 2,25 & 1,47 & 0,22 & 0,38 & 0,44 & 0,12 & 0,22 & 0,15 \\
\hline P6 & 3,42 & 5,80 & 1,56 & 0,28 & 0,50 & 0,45 & 0,16 & 0,28 & 0,17 \\
\hline P7 & 8,05 & 17,00 & 507 & 0,36 & 0,69 & 0,39 & 0,18 & 0,33 & 0,20 \\
\hline P8 & 14,00 & 42,00 & 9,39 & 0,38 & 0,68 & 0,43 & 0,18 & 0,33 & 0,20 \\
\hline P9 & 7,96 & 17,00 & 5,01 & 0,36 & 0,70 & 0,38 & 0,19 & 0,33 & 0,20 \\
\hline P10 & 3,41 & 5,78 & 1,56 & 0,30 & 0,52 & 0,48 & 0,17 & 0,29 & 0,18 \\
\hline P11 & 3,75 & 5,85 & 1,19 & 0,28 & 0,49 & 0,44 & 0,16 & 0,28 & 0,16 \\
\hline P12 & 6,27 & 13,00 & 3,09 & 0,36 & 0,67 & 0,38 & 0,19 & 0,32 & 0,18 \\
\hline P13 & 8,53 & 17,00 & 5,11 & 0,39 & 0,71 & 0,33 & 0,18 & 0,33 & 0,18 \\
\hline P14 & 6,32 & 13,00 & 3,12 & 0,36 & 0,67 & 0,38 & 0,19 & 0,33 & 0,18 \\
\hline P15 & 3,76 & 5,87 & 1,20 & 0,30 & 0,51 & 0,47 & 0,17 & 0,28 & 0,16 \\
\hline P16 & 1,68 & 0,97 & 0,65 & 0,24 & 0,39 & 0,40 & 0,15 & 0,25 & 0,15 \\
\hline P17 & 1,84 & 0,85 & 1,18 & 0,29 & 0,51 & 0,43 & 0,17 & 0,29 & 0,16 \\
\hline P18 & 1,93 & 0,76 & 1,55 & 0,31 & 0,56 & 0,43 & 0,17 & 0,29 & 0,16 \\
\hline P19 & 1,84 & 0,85 & 1,19 & 0,30 & 0,52 & 0,44 & 0,17 & 0,29 & 0,16 \\
\hline P20 & 1,68 & 0,98 & 0,66 & 0,26 & 0,41 & 0,42 & 0,15 & 0,25 & 0,16 \\
\hline P21 & 0,11 & 0,17 & 0,33 & 0,17 & 0,27 & 0,30 & 0,13 & 0,21 & 0,15 \\
\hline P22 & 0,10 & 0,15 & 0,48 & 0,20 & 0,33 & 0,35 & 0,14 & 0,24 & 0,15 \\
\hline P23 & 0,11 & 0,17 & 0,56 & 0,22 & 0,36 & 0,37 & 0,14 & 0,25 & 0,15 \\
\hline P24 & 0,10 & 0,15 & 0,48 & 0,21 & 0,34 & 0,36 & 0,14 & 0,24 & 0,15 \\
\hline P25 & 0,11 & 0,17 & 0,34 & 0,18 & 0,28 & 0,32 & 0,13 & 0,21 & 0,15 \\
\hline Average & 4,49 & 8,30 & 2,78 & 0,33 & 0,59 & 0,43 & 0,18 & 0,31 & 0,18 \\
\hline
\end{tabular}

During the analysis of the selected ES SYSTEM lighting fixture, the RAPID model took into account various weather conditions, such as air temperature or humidity. Measurements were made at two different heights. The obtained measurement results are summarized in Table 8.

Table 8. Measurement results

\begin{tabular}{|c|c|c|c|c|c|c|c|c|c|}
\hline \multirow{4}{*}{ 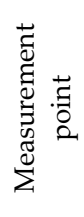 } & \multirow{2}{*}{\multicolumn{3}{|c|}{$\begin{array}{l}\text { EAv [lx] } \\
\text { Ground }\end{array}$}} & \multirow{2}{*}{\multicolumn{3}{|c|}{$\begin{array}{c}\text { EAv }[\mathrm{lx}] \\
16 \text { meters }\end{array}$}} & \multirow{2}{*}{\multicolumn{3}{|c|}{$\begin{array}{c}\text { EAv }[\mathrm{lx}] \\
26 \text { meters }\end{array}$}} \\
\hline & & & & & & & & & \\
\hline & $21 / 03 / 10$ & $21 / 05 / 24$ & $2021 / 06 / 10$ & $21 / 03 / 10$ & $21 / 05 / 24$ & $2021 / 06 / 10$ & $21 / 03 / 10$ & $21 / 05 / 24$ & $2021 / 06 / 10$ \\
\hline & $-4^{\circ} \mathrm{C}$ & $9^{\circ} \mathrm{C}$ & $17^{\circ} \mathrm{C}$ & $-4^{\circ} \mathrm{C}$ & $9^{\circ} \mathrm{C}$ & $17^{\circ} \mathrm{C}$ & $-4^{\circ} \mathrm{C}$ & $9^{\circ} \mathrm{C}$ & $17^{\circ} \mathrm{C}$ \\
\hline P1 & 3,10 & 4,31 & 4,06 & 0,24 & 0,36 & 0,32 & 0,18 & 0,20 & 0,19 \\
\hline P2 & 5,14 & 7,59 & 6,22 & 0,28 & 0,44 & 0,44 & 0,19 & 0,24 & 0,20 \\
\hline P3 & 7,70 & 9,84 & 7,88 & 0,35 & 0,45 & 0,49 & 0,23 & 0,26 & 0,22 \\
\hline P4 & 5,55 & 7,66 & 5,99 & 0,33 & 0,44 & 0,44 & 0,22 & 0,25 & 0,20 \\
\hline P5 & 3,86 & 4,75 & 4,05 & 0,28 & 0,28 & 0,29 & 0,20 & 0,21 & 0,19 \\
\hline P6 & 5,56 & 6,32 & 3,63 & 0,41 & 0,42 & 0,35 & 0,24 & 0,24 & 0,22 \\
\hline
\end{tabular}




\begin{tabular}{|c|c|c|c|c|c|c|c|c|c|}
\hline P7 & 10,57 & 10,70 & 10,39 & 0,53 & 0,51 & 0,44 & 0,28 & 0,27 & 0,26 \\
\hline P8 & 14,21 & 17,97 & 17,04 & 0,54 & 0,55 & 0,55 & 0,30 & 0,28 & 0,25 \\
\hline P9 & 10,03 & 9,97 & 8,77 & 0,46 & 0,50 & 0,49 & 0,25 & 0,25 & 0,25 \\
\hline P10 & 5,19 & 6,39 & 3,34 & 0,32 & 0,49 & 0,32 & 0,21 & 0,22 & 0,21 \\
\hline P11 & 5,98 & 4,72 & 3,17 & 0,41 & 0,43 & 036 & 0,23 & 0,26 & 0,23 \\
\hline P12 & 7,38 & 7,35 & 5,73 & 0,48 & 0,48 & 0,43 & 0,28 & 0,29 & 0,27 \\
\hline P13 & 8,23 & 10,09 & 8,44 & 0,49 & 0,55 & 0,50 & 0,30 & 0,30 & 0,26 \\
\hline P14 & 7,85 & 7,29 & 5,48 & 0,34 & 0,50 & 0,35 & 0,24 & 0,27 & 0,24 \\
\hline P15 & 5,09 & 4,46 & 2,80 & 0,33 & 0,32 & 0,31 & 0,22 & 0,25 & 0,21 \\
\hline P16 & 1,88 & 2,79 & 1,34 & 0,31 & 0,35 & 0,34 & 0,21 & 0,24 & 0,20 \\
\hline P17 & 2,53 & 3,34 & 1,72 & 0,33 & 0,43 & 0,36 & 0,22 & 0,25 & 0,24 \\
\hline P18 & 3,10 & 4,07 & 1,73 & 0,34 & 0,44 & 0,42 & 0,23 & 0,26 & 0,23 \\
\hline P19 & 2,32 & 3,44 & 1,61 & 0,23 & 0,37 & 0,30 & 0,18 & 0,25 & 0,18 \\
\hline P20 & 1,80 & 2,71 & 1,58 & 0,22 & 0,30 & 0,25 & 0,18 & 0,23 & 0,20 \\
\hline P21 & 0,17 & 0,96 & 0,10 & 0,17 & 0,26 & 0,20 & 0,16 & 0,22 & 0,17 \\
\hline P22 & 0,19 & 1,01 & 0,15 & 0,18 & 0,27 & 0,23 & 0,17 & 0,23 & 0,20 \\
\hline P23 & 0,21 & 1,27 & 0,16 & 0,20 & 0,28 & 0,27 & 0,18 & 0,25 & 0,20 \\
\hline P24 & 0,18 & 0,97 & 0,12 & 0,17 & 0,27 & 0,22 & 0,16 & 0,21 & 0,16 \\
\hline P25 & 0,14 & 0,85 & 0,11 & 0,16 & 0,26 & 0,17 & 0,15 & 0,18 & 0,15 \\
\hline Average & 4,72 & 5,63 & 4,22 & 0,32 & 0,40 & 0,35 & 0,21 & 0,24 & 0,21 \\
\hline
\end{tabular}

\section{Discussion}

The highest illuminance values, both on the ground surface and on the surfaces above the luminaire, were obtained in the case of the RACER luminaire. Almost two times lower values were achieved for the RAPID luminaire. In the case of the OCP MILEDIA lamp, the lowest illuminance values on the ground surface were obtained, but it does not translate into limiting light pollution. The luminaire generates a much larger amount of light directly into the upper half-space due to its spherical structure.

The errors that occur between the simulations in DIALux and the measurements in real conditions are usually around $20 \%$. However, it can be noticed that in the case of measurements from March $\left(-4{ }^{\circ} \mathrm{C}\right)$ and June $\left(17^{\circ} \mathrm{C}\right)$, the obtained values are very similar to those obtained in the simulation.

Table 9. Summary of the measurements results and calculations as well as the included atmospheric conditions

\begin{tabular}{|c|c|c|c|c|}
\hline \multicolumn{2}{|c|}{ Date } & $\begin{array}{l}2021 / 03 / 10 \\
-4^{\circ} \mathrm{C} \text {, dry }\end{array}$ & $\begin{array}{c}2021 / 05 / 24 \\
9^{\circ} \mathrm{C} \text {, dry } \\
\end{array}$ & $\begin{array}{c}2021 / 06 / 10 \\
17^{\circ} \mathrm{C} \text {, dry }\end{array}$ \\
\hline \multicolumn{2}{|c|}{ Hour } & $20: 00$ & $22: 00$ & $23: 00$ \\
\hline \multicolumn{2}{|c|}{ Conditions } & Dry & Dry & Dry \\
\hline Temperature & {$\left[{ }^{\circ} \mathrm{C}\right]$} & -4 & 9 & 17 \\
\hline $\begin{array}{l}\text { Dew point tempera- } \\
\text { ture }\end{array}$ & {$\left[{ }^{\circ} \mathrm{C}\right]$} & -5 & 7 & 15 \\
\hline Relative humidity & {$[\%]$} & 80 & 70 & 85 \\
\hline Pressure & {$[\mathrm{hPa}]$} & 1022 & 995 & 1015 \\
\hline Air density & {$\left[\mathrm{kg} / \mathrm{m}^{3}\right]$} & 1,286 & 1,209 & 1,188 \\
\hline Fog & [fraction] & 0 & 0 & 0 \\
\hline Wind & {$[\mathrm{m} / \mathrm{s}]$} & 1 & 1 & 2 \\
\hline Cloudy & [octanes] & Cloudless & Cloudless & Cloudless \\
\hline $\begin{array}{l}\text { Average illumination } \\
\text { on the ground }\end{array}$ & {$[\mathrm{lx}]$} & 4,72 & 5,63 & 4,22 \\
\hline Relative error & [\%] & $23 \%$ & $43 \%$ & $16 \%$ \\
\hline $\begin{array}{c}\text { Average illuminance } \\
\text { at } 16 \mathrm{~m}\end{array}$ & {$[\mathrm{~lx}]$} & 0,32 & 0,40 & 0,35 \\
\hline Relative error & {$[\%]$} & $19 \%$ & $29 \%$ & $20 \%$ \\
\hline
\end{tabular}




\begin{tabular}{|c|c|c|c|c|}
\hline $\begin{array}{c}\text { Average illuminance } \\
\text { at } 26 \mathrm{~m}\end{array}$ & {$[1 \mathrm{x}]$} & 0,21 & 0,24 & 0,21 \\
\hline Relative error & {$[\%]$} & $25 \%$ & $36 \%$ & $26 \%$ \\
\hline $\begin{array}{l}\text { The amount of light } \\
\text { escaping into the up- } \\
\text { per half-space }(16 \mathrm{~m})\end{array}$ & {$[\%]$} & $7 \%$ & $7 \%$ & $8 \%$ \\
\hline $\begin{array}{l}\text { The amount of light } \\
\text { escaping into the up- } \\
\text { per half-space }(26 \mathrm{~m})\end{array}$ & {$[\%]$} & $4 \%$ & $4 \%$ & $5 \%$ \\
\hline $\begin{array}{l}\text { Average luminous in- } \\
\text { tensity on the ground }\end{array}$ & [cd] & 853,34 & 1146,34 & 684,14 \\
\hline $\begin{array}{l}\text { Average luminous in- } \\
\text { tensity per } 16 \mathrm{~m}\end{array}$ & [cd] & 136,88 & 173,28 & 151,08 \\
\hline $\begin{array}{l}\text { Average luminous in- } \\
\text { tensity at } 26 \mathrm{~m}\end{array}$ & [cd] & 182,14 & 209,71 & 181,75 \\
\hline
\end{tabular}

Measurements carried out for the RAPID luminaire show that the distribution of the luminous flux of the luminaire changes depending on environmental conditions, air temperature or humidity. The conducted research did not allow to clearly define the extent to which particular parameters affect the luminous flux of a given luminaire. Therefore, the next test will be carried out in laboratory conditions, so that it is possible to carry out an analysis for individual humidity states, and to perform measurements in the case of fogging and various precipitation.

Work on improving the presented measurement method is still ongoing. However, already at this stage it can be concluded that it is possible to estimate the degree of light pollution using unmanned aerial vehicles and publicly available photometric meters [24].

The article was realized in the Department of Photonics, Electronics and Light Technology of the Bialystok University of Technology as part of the work WI/WE-IA/10/2020 funded by the Ministry of Science and Higher Education.

\section{References}

1. Chepesiuk, R. Missing the Dark: Health Effects of Light Pollution. Environ. Health Perspect. 2009, 117, 20-27.

2. Raap, T.; Pinxten, R.; Eens, M. Light pollution disrupts sleep in free-living animals. Sci. Rep. 2015, 5, 1-8.

3. Dominoni, D.M. The effects of light pollution on biological rhythms of birds: An integrated, mechanistic perspective. J. Ornithol. 2015, 156, 409-418.

4. Hölker, F.; Wolter, C.; Perkin, E.K.; Tockner, K. Light pollution as a biodiversity threat. Trends Ecol. Evol. 2010, 25, 681-682.

5. Stevens, R.G.; Zhu, Y. Electric light, particularly at night, disrupts human circadian rhythmicity: Is 24 a problem? Philosoph. Trans. R. Soc. B Biol. Sci. 2015, 370, 1-9.

6. Russart, K.L.G.; Nelson, R.J. Light at night as an environmental endocrine disruptor. Physiol. Behav. 2018, 190, 82-89.

7. Fonken, L.K.; Nelson, R.J. The Effects of Light at Night on Circadian Clocks and Metabolism. Endocr. Rev. 2014, 35, 648-670.

8. Wandachowicz K.: Wyznaczanie rozkładu luminancji we wnętrzach z uwzględnieniem kierunkowo-rozproszonych charakterystyk odbiciowych materiałów, Poznań: Politechnika Poznańska (2000)

9. Ściężor T., Wptyw stanu atmosfery na jasność łuny świetlnej bezchmurnego nocnego nieba, [chapter of monographs], 5. Ogólnopolska Konferencja na temat Zanieczyszczenia Światłem (2019)

10. Aydemir F., Internet of Things Based Parking Lot LED Lighting System, European Journal of Science and Technology, 17 (2019), 7176.

11. Kumar A., Raj Sahu A., Gupta S., Kumar Jaiswal N., Intelligent parking light in cars, National Conference on "Emerging Trends in Electronics \& Communication", Special Issue, 1 (2), 2015

12. Beccali M., Bonomolo M., Lo Brano V., Ciulla G., Di Dio V., Massaro F., Favuzza S., Energy saving and user satisfaction for a new advanced public lighting system, Energy Conversion and Management, 195, 1 September 2019, 943-957

13. Carli R., Dotoli M., Cianci E., An optimization tool for energy efficiency of street lighting systems in smart cities, IFAC-PapersOnLine, 50 (1), July 2017, 14460-14464

14. Sielachowska M., Zajkowski M., Szacowanie zanieczyszczenia światłem od obiektów sportowych za pomoca oprogramowania symulacyjnego DIALux, Poznan University of Technology Academic Journals. Electrical Engineering, 96 (2018), $219-229$

15. Polska Norma PN-EN 12464-2:2014-05. Oświetlenie miejsc pracy. Część 2: Miejsca pracy na zewnątrz.

16. European Standard EN 12464-2:2014-05.

17. Essystem.pl. Available online: https://www.essystem.pl/ (accessed on 2809 2021).

18. Tabaka P., Fryc I., Zależność poziomu zanieczyszczenia otoczenia światłem od kształtu krzywej światłości użytkowanej oprawy oświetleniowe, Kosmos T. 64, 2015 nr 4, s. 669-677 
19. Estrada-Garcia R. and others, Statistical modelling and satellite monitoring of upward light from public lighting, Lighting Research Technology, 48 (2016), 810-822

20. Tabaka P., Pilot Measurement of Illuminance in the Context of Light Pollution Performed with an Unmanned Aerial Vehicle, Remote Sens. 2020, 12(13), 2124

21. Sielachowska M., Zajkowski M., Assessment of Light Pollution Based on the Analysis of Luminous Flux Distribution in Sports Facilities, Springer: Engineer of the XXI Century 2019, 70, 139-150.

22. Sielachowska M., Tyniecki D., Zajkowski M., The Measurement Method of Light Distribution Emitted from Sports Facilities Using Unmanned Aerial Vehicles, VII Lighting Conference of the Visegrad Countries: LUMEN V4: Proceedings, Třebíč (2018), S. 149154

23. Sielachowska M., Tyniecki D., Zajkowski M, The Concept of Measuring Luminous Flux Distribution Emitted from Sports Facilities Using Unmanned Aerial Vehicles, Methods and Techniques of Signal Processing in Physical Measurements, Springer (2019), S. 306-318

24. Sielachowska M., Budzyński Ł., Zajkowski M., Light pollution measurements using unmanned aerial vehicles, Robotic Systems and Applications (under review).

25. Fiorentin P., Bettanini C., Bogoni D., Calibration of an Autonomous Instrument for Monitoring Light Pollution from Drones, Sensors (2019), 19(23). 